\title{
Segmentasi K-Means Citra Daun Tin Dengan Klasifikasi Ciri Gray Level Co Occurance Matrix
}

\author{
Muhammad Qomaruddina1, Dwiza Riana ${ }^{\mathrm{a} 2}$, Anton $^{\mathrm{a} 3}$ \\ aIlmu Komputer STMIK Nusa Mandiri \\ Jl. Kramat Raya No.18, RT.5/RW.7, Kwitang, Kec. Senen, Kota Jakarta Pusat 10450 \\ 114002209 @nusamandiri.ac.id \\ ${ }^{2}$ dwiza@nusamandiri.ac.id \\ 3anton@nusamandiri.ac.id
}

\begin{abstract}
Abstrak
Tanaman Tin dengan nama latin Ficus Caric adalah sejenis tanaman buah dari sejenis pohon yang banyak tumbuh di kawasan daerah tropis dan subtropis. Tanaman Tin saat ini sudah banyak dibudidayakan di Indonesia. Buah Tin memiliki buah yang berwarna kuning kecoklatan, dengan rasa yang manis. Cerotelium Fici adalah jenis penyakit karat daun yang menyerang pada daun tin, dan menjadi ancaman terbesar terhadap produksi buah tin. Penyakit lain yang menyerang pada tanaman tin adalah kutu kebul dan virus mosaik. Virus mosaik ini pertama kali muncul di California dan menyebar ke sebagaian besar wilayah Indonesia dan Amerika Serikat. Daun tin yang terinfeksi virus ini menjadi bintik-bintik cokelat menyebabkan pertumbuhan tanaman tin menjadi lambat dan cacat pada buah tin. Dalam perkembangan ilmu pengetahuan dan teknologi, cara untuk mendeteksi penyakit pada tanaman tin seperti karat daun, virus mosaik dan kutu kebul dapat dilakukan dengan bantuan pengolahan citra. Untuk itu penelitian ini bertujuan melakukan pengolahan citra berupa segmentasi $K$ Means pada citra daun tin yang dianalisa dengan ekstrasi fitur GLCM dan mengklasifikasikan Naïve Bayes untuk mendapatkan akurasi terbaik dalam klasifikasi penyakit citra daun tin. Setelah itu, dilakukan analisis tekstur menggunakan metode Grey Level Co-Occurance Matrix (GLCM) dan segmentasi K-Means clustring dalam pengolahan citra daun tin.
\end{abstract}

Kata kunci: K-Means, GLCM, Algoritma Nä̈ve Bayes, Segmentasi, Confusion Matrix

\section{Segmentation of K-Means Image of Tin Leaves with Characteristic Classification of Gray Level Co Occurance Matrix}

\begin{abstract}
Tin plant with the Latin name Ficus Caric is a type of fruit plant from a type of tree that grows in many tropical and subtropical regions. Tin plants are currently widely cultivated in Indonesia. Tin fruit has brownish-yellow fruit, with a sweet taste. Cerothelium fic is a type of leaf rust disease that attacks the leaves of figs and is the biggest threat to the production of figs. Other diseases that attack tin plants are whitefly and mosaic virus. This mosaic virus first appeared in California and spread to most parts of Indonesia and the United States. Figs infected with this virus become brown spots causing slow growth of figs and deformities in the figs. In the development of science and technology, ways to detect diseases in tin plants such as leaf rust, mosaic virus, and whitefly can be done with the help of image processing. For this reason, this study aims to perform image processing in the form of K-Means segmentation on tin leaf images analyzed by GLCM feature extraction and to classify Naïve Bayes to get the best accuracy in the classification of tin leaf disease images. After that, texture analysis was carried out using the Gray Level Co-Occurance Matrix (GLCM) method and K-Means clustering segmentation in the image processing of tin leaves.
\end{abstract}

Keywords: K-Means, GLCM, Naïve Bayes Algorithm, Segmentation, Confusion Matrix

\section{Pendahuluan}

Tanaman Tin (Ficus Caric) merupakan sejenis tumbuhan penghasil buah yang berasal dari Asia Barat. Nama Tin diambil dari bahasa Arab, yang berarti buah ara atau pohon ara. Di Indonesia, Tanaman Tin mulai banyak digemari dan dikembangkan dikarenakan memiliki banyak khasiat dalam tanaman tersebut. Berbagai penelitian menyebutkan bahwa kandungan senyawa polifenol yang terdapat pada daun dan buah Tin dapat digunakan guna menghambat pertumbuhan sel kanker[1] dan antikanker payudara[2]. 
Permintaan Tanaman Tin yang melonjak sering tidak dapat dipenuhi membuat Tanaman Tin menjadi langka di Indonesia. Kelangkaan tersebut disebabkan oleh penyakit dan virus yang menyerang pada Tanaman Tin. Misalkan saja penyakit Cerotelium Fici yang muncul pada musim hujan membuat daun Tin yang telah terinfeksi berubah warna menjadi cokelat kekuningan, daun rontok hingga membuat Tanaman Tin menjadi lemah yang mempengaruhi ke perkembangan buah[3].

Penyakit lain yang menyerang pada tanaman tin adalah jenis virus mosaik, penyakit ini pertama kali muncul di California dan menyebar ke sebagaian besar wilayah Indonesia dan Amerika Serikat. Daun tin yang terinfeksi virus ini menjadi bintik-bintik cokelat menyebabkan pertumbuhan menjadi lambat dan cacat pada buah Seringkali penyakit yang menyerang Tanaman Tin tidak segera bisa diatasi dikarenakan harus dilakukan pemeriksaan dan analisa jenis penyakitnya terlebih dahulu. Selain virus mosaik Hama Bemisia Tabaci atau lebih dikenal dengan sebutan kutu kebul merupakan salah satu hama yang banyak menyerang tanaman. Bagian yang diserang dari hama kutu kebul ini yaitu daun dan batang, sehingga mengakibatkan daun menjadi menguning dan kering, jika dibiarkan maka daun-daun dari tanaman tersebut berguguran dan berakibat kematian pada tanaman tersebut[4]. Adapun dalam penanganannya dapat terjadi kesalahan seperti salah mendeteksi jenis penyakit dan salah melakukan pengobatannya[5] [3].

Segmentasi Algoritma K-Means pada Daun Tin dapat digunakan untuk menganalisa penyakit yang ada pada daun Tin[6][7]. Melalui fitur Gray level cooccurrence metrices (GLCM) akan didapatkan tekstur correlation, energy, homogeneity, dan contrast dari daun Tin. Kemudian dengan menggunakan metode algoritma C4.5 dan Naïve Bayes dilakukan pembagian wilayahwilayah homogen guna mendapatkan hasil analisa penyakit daun Tin dengan akurat[8][9].

Hasil citra pelatihan daun tin sakit dan sehat selanjutnya dilakukan pegujian dengan confusion matrix dan dilakukan pengujian dengan cross validation dengan jumlah k-fold sebanyak 10 untuk mendapatkan keakuratan dari metode yang diusulkan[10][11]. Pengukuran dua metode algoritma c4.5 dan naïve bayes dilakukan dengan confusion matrix sehingga menghasilkan metode terbaik untuk memprediksi daun tin sakit[12].

Dengan melakukan Riset Segmentasi citra daun tin sakit dan sehat secara digitalisasi ini diharapkan dapat mendeteksi penyakit yang ada pada tanaman Tin dengan cepat sehingga mampu dilakukan penanganannya dengan tepat, efektif dan efisien.

\section{Metode Penelitian}

\section{A. Metode Penelitian}

Bagian ini menguraikan tentang teori-teori yang digunakan dalam penelitian ini mulai dari teknik pengolahan citra hingga metode-metode yang digunakan dalam penelitian segmentasi citra daun tin. Berikut beberapa teori dan metode yang digunakan :

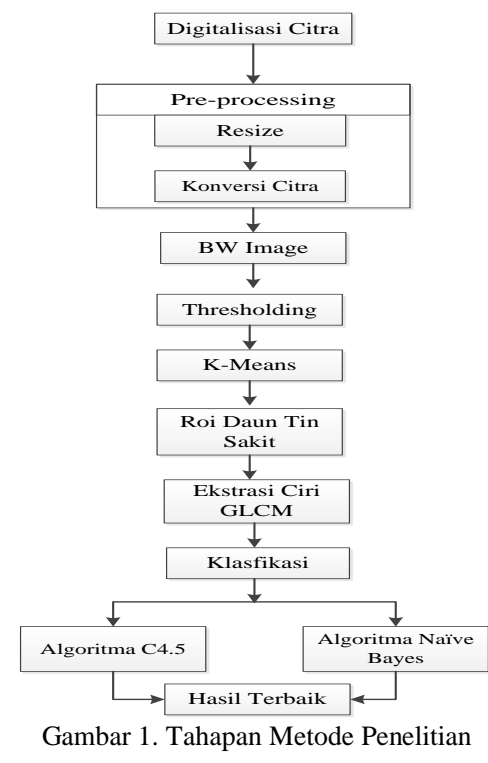

\section{1) Digitalisasi Citra}

Digitalisasi citra yaitu suatu metode yang dilakukan untuk merubah citra dari citra analog menjadi citra digital, dalam bentuk piksel agar komputer dapat melakukan proses dalam manipulasi pada citra tersebut yang menghasilkan tampilan lebih baik dan indah. Digitalisasi citra sebagai penciptaan citra digital, seperti struktur bagian dari suatu objek. Digitalisasi citra diklasifikasikan berdasarkan jenis radiasi elektromagnetik yang disebut sebagai gelombang lain yang melewati atau memantulkan objek, sehingga dapat mengirimkan informasi berupa citra. Proses digitalisasi citra yaitu suatu teknologi memanipulasi bit-bit atau piksel untuk dapat meningkatkan kualitas citra atau membuat sudut pandang yang berbeda untuk mengekstrak nilai informasi dari suatu citra secara digital, dengan menggunakan algoritma komputer[13]. Peralatan penunjang dalam proses digitalisasi citra daun tin yaitu seperti camera digital, Smartphone, USB Webcam, Scanner dan mikroskop digital[14].

Pada tahapan ini dimana citra analog daun tin sehat dan sakit sebanyak 120 citra daun tin yang terdiri dari 40 citra daun tin sakit dan 40 citra daun tin sehat dilakukan digitalisasi citra untuk dapat diolah ke tahapan selanjutnya. Dari 80 citra daun tin sehat dan sakit dibagi menjadi $60 \%$ untuk dijadikan data latih dan $40 \%$ dijadikan data uji yang bertujuan untuk mendapatkan data set citra digital dari daun tin.

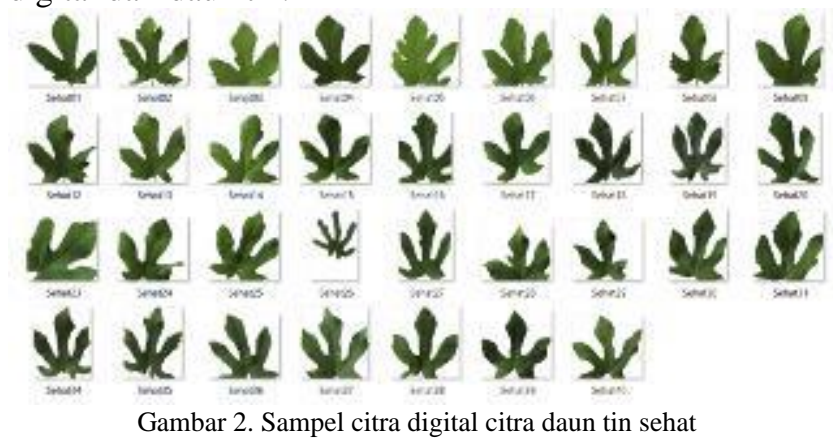




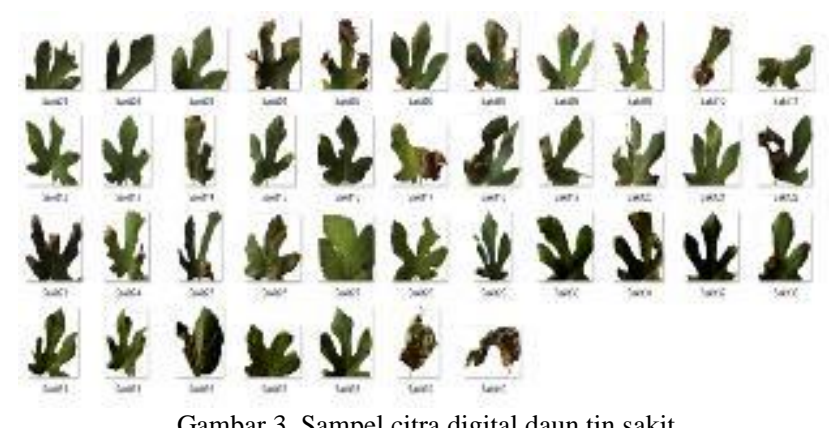

Gambar 3. Sampel citra digital daun tin sakit

\section{2) Resize}

Proses melakukan perubahan ukuran luas citra dari lebih besar atau lebih kecil dari ukuran aslinya merupakan proses resizing. Dalam tahapan preprocessing merubah ukuran citra asli atau melakukan resize, hal ini dilakukan agar semua citra yang diinputkan memiliki ukuran citra yang sama, sehingga akan memudahkan dalam proses mengolah citra ke tahapan berikutnya[15].

\section{3) Konversi Citra}

Pada tahapan konversi Citra terdapat beberapa tahapan-tahapan pemrosessan yang dilakukan. Proses yang pertama melakukan proses resizing yang berfungsi untuk menyamakan ukuran citra input agar ukuraannya seragam. Kemudian dilakukan konversi citra RGB ke Grayscale dengan melakukan operasi komplemen agar objek berwarna putih dan background berwarna hitam. Selanjutnya dilakukan operasi morfologi untuk menyempurnakan hasil segmentasi[16].

\section{4) Segmentasi Citra}

Segmentasi membagi citra ke dalam sejumlah region atau obyek. Level untuk pembagian tergantung pada masalah yang diselesaikan. Maka, Segmentasi seharusnya berhenti ketika obyek yang diinginkan dalam aplikasi telah terisolasi. Misalnya, pemeriksaan otomatis pada rakitan produk elektronik. Yang diinginkan adalah analisis citra produk dengan tujuan untuk mengetahui ada atau tidaknya penyimpangan tertentu seperti salah komponen, atau lintasan hubungan yang terputus[17].

Algoritma segmentasi citra umumnya didasarkan pada satu dari dua properti nilai intensitas diskontinuitas dan similaritas. Dalam kategori pertama, pendekatannya adalah memecah atau memilah citra berdasarkan perubahan kasar dalam intensitas, seperti tepi dalam citra. Pendekatan utama kategori kedua didsarkan pada pemecahan citra ke dalam region yang sama menurut sejumlah kriteria yang didefinisikan, seperti thresholding, region growing, region splitting and merging[18].

\section{a) Bw Image}

Citra yang sudah dikonversi menjadi citra Grayscale yang hanya mempunyai nilai derajat keabuan. Selanjutnya diubah ke citra biner menjadi citra hitam dan putih. Citra biner direpresentasikan dengan dua intensitas warna pada tiap pikselnya yaitu 0 dan 1 , dimana nilai 1 mewakili warna hitam dan nilai 0 mewakili warna putih. Pada Citra biner, piksel-piksel objek bernilai 1 dan pikselpiksel latar belakang bernilai 0[19].

\section{b) Thresholding}

Karena properti intuitif dan kesederhanaanya dalam implementasi, Thresholding citra menjadi titik pusat dalam aplikasi segmentasi citra. Di sini akan dibahas mengenai cara pemilihan nilai thresholding secara otomatis dan memperhatikan metode untuk bermacammacam thresholding menurut properti ketetanggan citra lokal [20].

Andaikan bahwa histogram intensitas yang ditunjukan pada gambar 2.1 yang berkaitan dengan citra $\mathrm{f}(\mathrm{x}, \mathrm{y})$, yang terdiri dari obyek terang pada background gelap, maka piksel obyek dan backgorund mempunyai level intensitas yang dikelompokkan ke dalam dua mode dominan. Satu cara yang jelas untuk mengesktrak sembarang titik $(x, y)$ untuk dimana $f(x, y)>T$ disebut object point. Sedangkan yang lain disebut background point. Dengan kata lain, citra yang di-thresholding $\mathrm{g}(\mathrm{x}, \mathrm{y})$ didefinisikan sebagai [21] :

$$
g(x, y)=\left\{\begin{array}{l}
1 \text { jika } f(x, y) \geq T \\
0 \text { jika } f(x, y<T
\end{array}\right.
$$

Piksel yang diberi nilai 1 berkaitan dengan obyek sedangkan piksel yang diberi nilai 0 berkaitan dengan backgorund. Ketika $\mathrm{T}$ adalah konstanta, pendekatan ini disebut global thresholding.

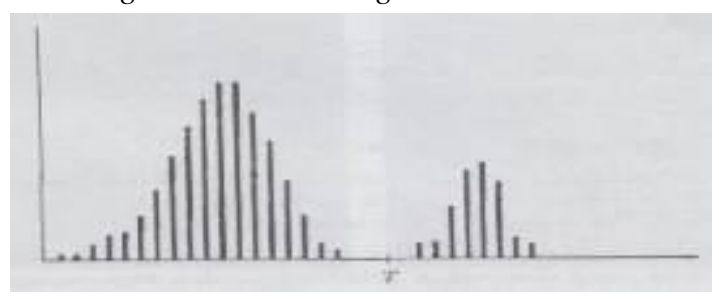

Gambar 4. Pemilihan thresholding secara analis visual histogram bimodal

\section{c) Region Growing}

Sebagaimana implikasi namanya, region growing adalah prosedur yang mengelompokan piksel atau subregion kedalam region yang lebih besar berdasakan pada kriteria yang sudah ditentukan untuk pertumbuhannya. Pedekatan dasarnya adalah memulai dengan titik seed dan dari sini menumbuhkan region oleh penambahan pada setiap seed piksel tetangga yang memunya properti sama dengan seed (seperti range spesifik dari gray level atau warna) [17].

Pemilihan sejumlah satu atau lebih starting point sering menjadi dasar masalah. Satu prosedur untuk menghitung pada setiap piksel kesamaan sekumpulan properti yang akhirnya akan digunakan untuk memberi nilai piksel pada region selama proses growing. Jika hasil dari komputasi ini menunjukan cluster nilai, piksel yang tempat propertinya dekat cluster centroid dapat digunakan sebagai seed [21].

Pemilihan kesamaan kriteria tidak hanya tergantung pada masalah tersebut, tetapi juga pada jenis data citra yang tersedia. Ketika citranya monokrom analisis region harus dilakukan dengan sejumlah deskriptor yang didasarkan pada level intensitas (seperti momen atau tekstur yang dan properti spasial)[21]. 
Deskriptor itu sendiri dapat memberikan hasil yang tidak benar jika informasi konekvitas (adjacency) tidak digunakan dalam proses region growing. Misalnya, visualisasi susunan random piksel dengan hanya tiga perbedaan nilai intensitas. Pengelompokan piksel dengan level intensitas yang sama untuk membentuk "region" tanpa perhatian konektivitas akan memberikan hasil segmentasi yang kurang bermakna[17].

\section{d) Region Splitting And Merging}

Metode split-and-merge adalah salah satu metode segmentasi yang banyak digunakan. Split-andmerge dengan struktur quadtree adalah pemecahan populer pada segmentasi citra karena sederhana dan komputasinya efisien. Algoritma split-and-merge[22] dengan struktur quadtree tidak mampu menyesuaikan dengan semantik citra. Tepi-tepi segmen yang dibentuk oleh algoritma ini hanya mempunyai dua arah (vertikal dan horisontal) dan posisinya dibatasi oleh batas node quadtreee. Kesalahan dalam arah dan posisi tepi akan mengakibatkan kesalahan dalam segmentasi[22].

Metode ini dimulai dengan mengasumsikan bahwa keseluruhan citra (region $\boldsymbol{R}$ ) adalah homogen. Jika asumsi ini tidak terpenuhi, maka citra dibagi (split) menjadi empat subregion $\left(\boldsymbol{R}_{\mathbf{1}}, \boldsymbol{R}_{\mathbf{2}}, \boldsymbol{R}_{\mathbf{3}}, \boldsymbol{R}_{\mathbf{4}}\right)$ yang luasnya sama. Prosedur ini dilaksanakan secara rekursif terhadap subregion-subregion yang dihasilkan sampai didapatkan subregion-subregion yang homogen. Subregion subregion yang bertetangga akan digabung (merge) jika memenuhi kriteria [22].

\section{5) Segmentasi K-Means}

Metode clustering non hirarki atau disebut dengan $K$-means clustering, merupakan pengelompokan suatu data menggunakan metode K-Means yang secara umum dapat dilakukan dengan algoritma dasar seperti menentukan jumlah cluster awal, menempatkan centroid sesuai dengan jumlah cluster secara acak, mengalokasikan cluster yang sesuai dengan centroid dan menggunakan perhitungan jarak terdekat. Data yang digunakan untuk dikluster diperoleh dengan membandingkan jarak (distance) untuk menentukan tingkat kesamaan atau ketidaksamaan dua vektor fitur [21].

Proses segmentasi menggunakan metode $K$ Means dengan menghitung jarak kemiripan warna dari hasil segmentasi menggunakan metode K-Means. Selanjutnya pendekatan warna menggunakan Euclidean Distance untuk mendeteksi penyakit tanaman daun jagung yaitu antara penyakit hawar daun dan bercak daun didapatkan presentase pengujian sistem sebesar 90\%[23].

\section{6) Region Of Interest}

Region of Interest (ROI) adalah bagian salah satu proses tekhnik segmentasi untuk mengolah citra digital sehingga pengguna mampu mengolah citra yang mengandung nilai informasi dari data citra yang dikehendaki. ROI bekerja dalam pengkodean secara berbeda pada bagian wilayah tertentu dari citra digital, sehingga bagian wilayah citra yang lebih penting akan memiliki kualitas informasi citra yang lebih baik dari wilayah citra disekitarnya[7]. Untuk mendapatkan region of interest (ROI) suatu citra, sebelumnya dilakukan region filling terlebih dahulu guna memisahkan citra dengan background-nya[24].

Algoritma sederhana untuk region filling didasarkan pada sejumlah dilasi, komplementasi, dan interseksi dinyatakan himpunan yang berisi subset dimana elemen-elemennya adalah boundary titik-titik 8-connected dari region. Dimulai dengan sebuah titik $\mathrm{p}$ didalam boundary, tujuannya adalah untuk mengisi semua region dengan nilai 1. Jika mengikuti konvensi bahwa semua titik non-boundary (background) diberi nilai 0 , maka $\mathrm{p}$ harus diberi nilai 1 untuk memulai. Prosedur dibawah ini adalah untuk mengisi region dengan nilai 1[24]:

$$
X k=\left(X_{k-1}+B\right) \cap A^{c} K=1,2,3 \ldots
$$

Dimana $X_{0}=p \operatorname{dan} B$ adalah sterl simetrik. Algoritma berhenti pada iterasi langkah ke $\mathrm{k}$ jika $X_{k}=X_{k-1}$ himpunan union dari Xdan A mengisi daerah isian dan boundary-nya[24].

Proses dilasi akan mengisi semua daerah jika belum diperiksa. Interseksi pada setiap langkah dengan $A^{c}$ membatasi hasil agar selalu didalam region yang ditentukan. Hal tersebut adalah proses morfologi yang dapat diisyaratkan untuk mencapai properti yang diharapkan[24].

\section{7) Data Set Pelatihan dan Pengujian}

Klasifikasi algoritma $\mathrm{C} 4.5$ dan algoritma Nä̈ve Bayes pada data set citra pelatihan dan pengujian ditujukan untuk mencari hasil terbaik dalam tingkat akurasi terbaik dari ekstrasi fitur contrast, correlation, energy, homogeneity. Akurasi terbaik yang didadapat dari pengklasifikasian algoritma $\mathrm{C} 4.5$ dan algoritma Nä̈ve Bayes seperti jumlah data benar, jumlah data salah, dan nilai akurasi terbaik dari kedua algoritma seperti C4.5 dan algoritma Naïve dalam mengklasifikasi citra pelatihan dan pengujian citra daun tin[25].

\section{8) Metode Analisis Tekstur GLCM}

Gray level Co-occurrance Matrix (GLCM) adalah metodologi pemrosesan gambar yang digunakan untuk menggambarkan hubungan spasial antara nilai-nilai abuabu dalam citra 2 dimensi. Sejak itu, GLCM telah digunakan secara luas dalam berbagai aplikasi. Dari semua teknik analisis tekstur, saat ini mungkin yang paling banyak digunakan adalah yang didasarkan pada algoritma GLCM[26]. Metode GLCM sebagai cara untuk mengklasifikasikan citra menggunakan pengukuran statistik urutan kedua[27].

Matrik intensitas co-occurrence merupakan suatu matrik yang menggambarkan frekuensi munculnya pasangan dua piksel dengan intensitas tertentu dalam jarak dan arah tertentu dalam citra. Matriks intensitas co-occurrence $p\left(i_{1}, i_{2}\right)$ didefinisikan dengan dua langkah sederhana sebagai berikut. Langkah pertama adalah menentukan lebih dulu jarak antara dua titik dalam arah vertikal dan horizontal (vektor $\mathrm{d}=(\mathrm{dx}, \mathrm{dy})$ ), dimana besaran $\mathrm{dx}$ dan dy dinyatakan dalam piksel sebagai unit terkecil dalam citra digital. Langkah kedua adalah 
menghitung pasangan piksel-piksel yang mempunyai nilai intensitas $i_{1}$ dan $i_{2}$ dan berjarak di piksel dalam citra. Kemudian hasil setiap pasangan nilai intensitas diletakkan pada matriks sesuai dengan koordinatnya, dimana absis untuk nilai intesitas $i_{1}$ dan kordinat untuk nilai intensitas $i_{2}$. Sebagai contoh misalnya citra berukran $5 \times 5$ piksel dan mempunyai intensitas 0,1 dan 2 seperti terlihat pada gambar 2.2, akan dianilisis teksturnya. Karena hanya ada tiga nilai intensitas $(0,1$ dan 2$)$ maka matriks $p\left(i_{1}, i_{2}\right)$ akan berukuran $3 \times 3$. Bila jarak antar piksel ditentukan $(1,1)$, yang berarti satu piksel ke kanan dan satu piksel ke bawah maka pasangan piksel hang harus dihitung adalah berjarak satu piksel dengan arah sudut $135^{\circ}$ dari sumbu vertikal. Dalam citra berukuran $5 \times 5$ ada 16 pasangan yang memenuhi syarat ini[17].

Kemudian pasangan piksel, dimana piksel pertama mempunyai nilai intensitas $i_{1}$ dan pasangan yang berjarak d mempunyai nilai intesitas $i_{2}$, dihitung dan dimasukan kedalam kolom ke- $i_{1}$ dan baris ke $i_{2}$, pada matriks $p\left(i_{1}, i_{2}\right)$, menggunakan contoh pada gambar 2.2 , ada tiga pasangan pisel yang mempunyai nilai intensitas $(2,1)$ dan terpisah dengan jarak d seperti yang ditetapkan semula, maka nilai kordinat yang bersangkutan pada matriks $p\left(i_{1}, i_{2}\right)$ adalah 3 . Matriks yang sudah lengkap diisi terlihat pada gambar 2.3[28].

Selanjutnya tiap elemen matriks $p\left(i_{1}, i_{2}\right)$ perlu dinormalisasikan dengan cara membaginya dengan bilangan yang merupakan jumlah total dari pasangan piksel. Pada contoh, tiap elemen dibagi dengan 16 karena jumlah tiap pasangan dalam gambar 2.3 adalah 16. Nilainilai elemen matriks setelah dinormalisasi kemudian dapat diperlakukan sebagai fungsi probabilitas karena jumlah seluruh elemen sekarang bernilai 1 [28].

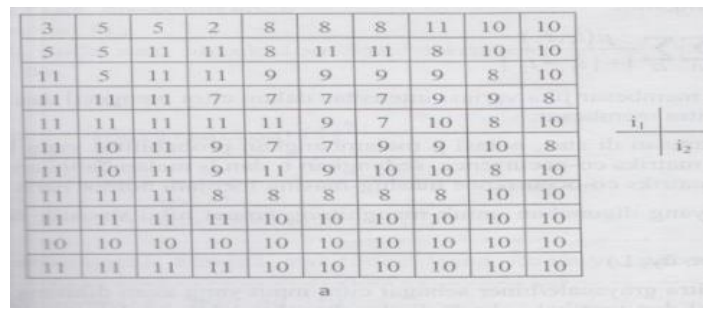

Gambar 5. Citra Berukuran 5x5 Dengan Intensias 0,1 Dan 2

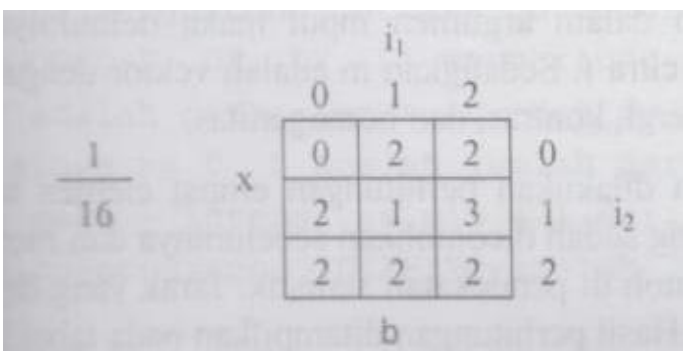

Gambar 6. Matriks Intensitas Co-Occurance Untuk D=(1,1)

Salah satu sifat tekstur dapat diambil dari statistik nilai intensitas abu-abu dalam citra, yaitu rata-rata (mean). Nilai mean dari suatu sebaran nilai intensitas citra abu-abu dapat dicari tanpa bantuan matriks co-occurance, karena sifatnya sederhana. Tetapi untuk mengesktrak sifat-sifat lain dalam analisis tekstur, matriks co-occuorece sangat diperlukan untuk membantu perhitungan sifat-sifat yang akan diekstrak dari citra tersebut.

Sebuah fitur untuk mengukur keteracakan dari distribusi intensitas disebut entropi dan didefinisikan sebagai berikut[28]:

Entropi $=-\sum_{i 1} \sum_{i 2} p\left(i_{1}, i_{2}\right) \log p\left(i_{1}, i_{2}\right) \ldots \ldots$ (1)

Nilai entropi maksimum jika semua elemen $p\left(i_{1}, i_{2}\right)$ sama, yaitu matriks yang berhubungan dengan citra dimana tidak terdapat susunan tertentu dalam pasangan intensitas dengan jarak vektor tertentu (daerah konstan).

Fitur yang lain adalah energi, yaitu fitur untuk mengukur konsentrasi pasangan intensitas pada matriks cooccurance, dan didefinisikan dengan :

Energi $=\sum_{i 1} \sum_{i 2} p^{2}\left(i_{1}, i_{2}\right)$.

Nilai energi makin membesar jika pasangan piksel yang memenuhi syarat matriks intensitas co-occurance terkonsentrasi pada beberapa koordinat dan mengecil jika letaknya menyebar. Fitur lainnya yaitu kontras yang digunakan mengukur kekuatan perbedaan intensitas dalam citra dan dinyatakan dengan :

Kontras $=\sum_{i 1} \sum_{i 2}\left(i_{1}, i_{2}\right)^{2} p\left(i_{1}, i_{2}\right)$.

Nilai kontras membesar jika variasi intensitas dalam citra tinggi, dan menurun jika variansinya rendah. Kebalikan dari kontras adalah homogenitas, yaitu untuk mengukur kehomogenan variasi intensitas dalam citra, dan didefinisikan dengan :

Homogenitas $=\sum_{i 1} \sum_{i 2} \frac{p\left(i_{1}, i_{2}\right)}{1+\left|i_{1}-i_{2}\right|} \ldots \ldots \ldots \ldots \ldots$........

Nilai homogenitas membesar jika variansi intesitas dalam citra mengecil dan sebaliknya mengecil jika variansi dalam citra membesar.

\section{9) Algoritma Nä̈ve Bayes}

Algoritma Nä̈ve Bayes merupakan suatu metode yang tidak memiliki aturan. Algoritma Nä̈ve Bayes merupakan suatu cabang algoritma matematika yang dikenal dengan teori probabilitas untuk mencari peluang terbesar dari kemungkinan klasifikasi, dengan cara melihat frekuensi tiap klasifikasi pada data training. Algoritma Nä̈ve Bayes termasuk merupakan suatu metode klasifikasi yang popoler, dan masuk dalam 10 algoritma terbaik dalam data mining. Algoritma ini dikenal dengan nama Idiot's Bayes, Simple Bayes dan Independece Bayes[25].

Klasifikasi algoritma Naive Bayes merupakan pengklasifikasian statistik yang dapat digunakan untuk memprediksi probabilitas keanggotaan suatu class. Klasifikasi Bayesian didasarkan pada teorema Bayes, yang diambil dari nama seorang ahli matematika yang juga menteri Prebysterian Inggris, Thomas Bayes (17021761). Klasifikasi bayesian memiliki kemampuan klasifikasi serupa dengan decision tree dan neural network. Bayes rule digunakan untuk menghitung probabilitas suatu class. Algoritma Naive Bayes memberikan suatu cara mengkombinasikan peluang terdahulu dengan syarat kemungkinan menjadi sebuah 
formula yang dapat digunakan untuk menghitung peluang dari tiap kemungkinan yang terjadi[25].

\section{0) Algoritma Decision Tree (C4.5)}

Perkembangan dari Algoritma ID3, adalah Algoritma C4.5 yang diperkenalkan oleh J. Ros Quinlan, yang diperuntukan untuk membentuk pohon keputusan atau biasa dikenal dengan decision tree. Dan dianggap sebagai salah satu pendekatan yang paling populer dalam pengklasifikasian. Dalam klasifikasi decision tree atau pohon keputusan terdiri dari sebuah node yang membentuk akar. Node akar tidak memiliki input, node lain yang bukan sebagai akar tetapi tepat satu input disebut sebagai node internal atu test node, sedangkan node lainnya dinamakan daun. Daun mewakili nilai target yang paling tepat dari satu class[25].

Pohon keputusan dapat dibuat dengan melakukan pembagian nilai-nilai pada atribut menjadi cabang untuk setiap kemungkinan. Pohon keputusan bekerja dengan melakukan penelusuran dari akar hingga ke cabang sampai class suatu objek ditemukan. Instance diklasifikasikan dengan mengarahkan dari akar pohon sampai ke daun sesuai dengan hasil tes melalui node internal[25].

Konsep dasar dari algoritma $\mathrm{C} 4.5$ yaitu mengubah data menjadi pohon keputusan (decision tree) dan aturanaturan keputusan (rule). C4.5 adalah algoritma yang cocok untuk masalah klasifikasi dan data mining. C4.5 memetakan nilai atribut menjadi class yang dapat diterapkan untuk klasifikasi baru[25].

\section{HASIL DAN PEMBAHASAN}

\section{1) Bw Image}

Pada tahap bw image, citra daun tin diubah ke dalam citra $b w$ image. Hasil konversi citra $b w$ image dapat dilihat pada tabel I sebagai berikut:

TABEL I

HASIL KONVERSI CITRA $B W I M A G E$

\begin{tabular}{|c|c|c|c|}
\hline No & Nama File & Citra RGB & Bw Image \\
\hline 1 & Sehat01.jpg \\
\hline 2 & Sehat02.jpg \\
\hline 3 & Sehat03.jpg \\
\hline 4 & Sehat04.jpg & \\
\hline 5 & Sehat05.jpg & \\
\hline 6 & Sakit01.jpg & \\
\hline
\end{tabular}

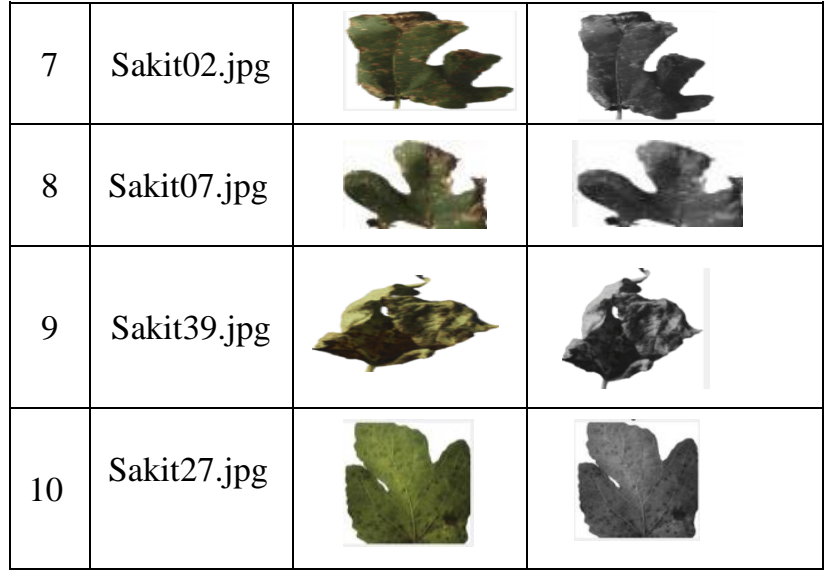

\section{2) Segmentasi Thresholding}

Pada tahap Segmentasi Thresholding citra daun tin yang sebelumnya sudah dilakukan perubahan menjadi citra bw image kemudian dilakukan pemisahan antara objek dengan background. Dapat dilihat pada Tabel II citra hasil Thresolding lebih dominan hitam. Berikut hasil segmentasi Thresholding :

TABEL II

HASIL SEGMENTASI THRESHOLDING

\begin{tabular}{|c|c|c|c|c|}
\hline No & Nama File & Citra RGB & $\begin{array}{c}\text { Bw } \\
\text { Image }\end{array}$ & Thresholding \\
\hline 1 & Sehat01.jpg & & & \\
\hline 2 & Sehat02.jpg & & & \\
\hline 3 & Sehat03.jpg & & & \\
\hline 4 & Sehat04.jpg & & & \\
\hline 5 & Sehat05.jpg & & & \\
\hline 6 & Sakit01.jpg & & & \\
\hline 7 & Sakit02.jpg & & & \\
\hline 8 & Sakit07.jpg & & & \\
\hline 9 & Sakit39.jpg & & & \\
\hline 10 & Sakit27.jpg & & & \\
\hline
\end{tabular}

3) Segmentasi Algoritma K-Means

Pada tahap ini dilakukan proses klustering citra daun tin dengan cara mengkonversi ruang warna citra 
menjadi ruang warna $L^{*} a * b$. Selanjutnya komponen a dan b dari citra $\mathrm{L}^{*} \mathrm{a} * \mathrm{~b}$ digunakan sebagai nilai masukan dalam Algoritma K-Means. Hasil segmentasi algoritma K-Means dapat dilihat pada tabel 4.4 sebagai berikut:

TABEL III

HASIL SEGMENTASI $K$-MEANS

\begin{tabular}{|c|c|c|c|c|}
\hline No & Nama File & $\begin{array}{l}\text { Citra } \\
\text { RGB }\end{array}$ & $\begin{array}{c}\text { Bw } \\
\text { Image }\end{array}$ & $\begin{array}{c}\text { Thresholdin } \\
\mathrm{g}\end{array}$ \\
\hline 1 & Sehat01.jpg & & & \\
\hline 2 & Sehat02.jpg & & & \\
\hline 3 & Sehat03.jpg & & & \\
\hline 4 & Sehat04.jpg & & & \\
\hline 5 & Sehat05.jpg & & & \\
\hline 6 & Sakit01.jpg & & & \\
\hline 7 & Sakit02.jpg & & & \\
\hline 8 & Sakit07.jpg & & & \\
\hline 9 & Sakit39.jpg & & & \\
\hline 10 & Sakit27.jpg & & & \\
\hline
\end{tabular}

4) Region Of Interest

Setelah segmentasi dengan Algoritma K-Means, untuk menandai area citra daun tin sehat dan sakit maka dilakukan Region of Interest. Hasil dari Region Of Interest seperti terlihat pada tabel 4.5 dibawah ini selanjutnya akan dihitung nilai ekstrasi cirinya dengan menggunakan GLCM (Gray Level Co-Occurrence Matrix).

TABEL IV

HASIL REGION OF INTEREST

\begin{tabular}{|c|c|c|c|c|}
\hline No & Nama File & $\begin{array}{c}\text { Threshold } \\
\text { ing }\end{array}$ & $\begin{array}{c}\text { Segmen } \\
\text { tasi } \\
\text { K- } \\
\text { Means }\end{array}$ & $\begin{array}{c}\text { Region Of } \\
\text { Interest }\end{array}$ \\
\hline 1 & Sehat01.jpg & & \\
\hline 2 & Sehat02.jpg & & \\
\hline 3 & Sehat03.jpg & & \\
\hline
\end{tabular}

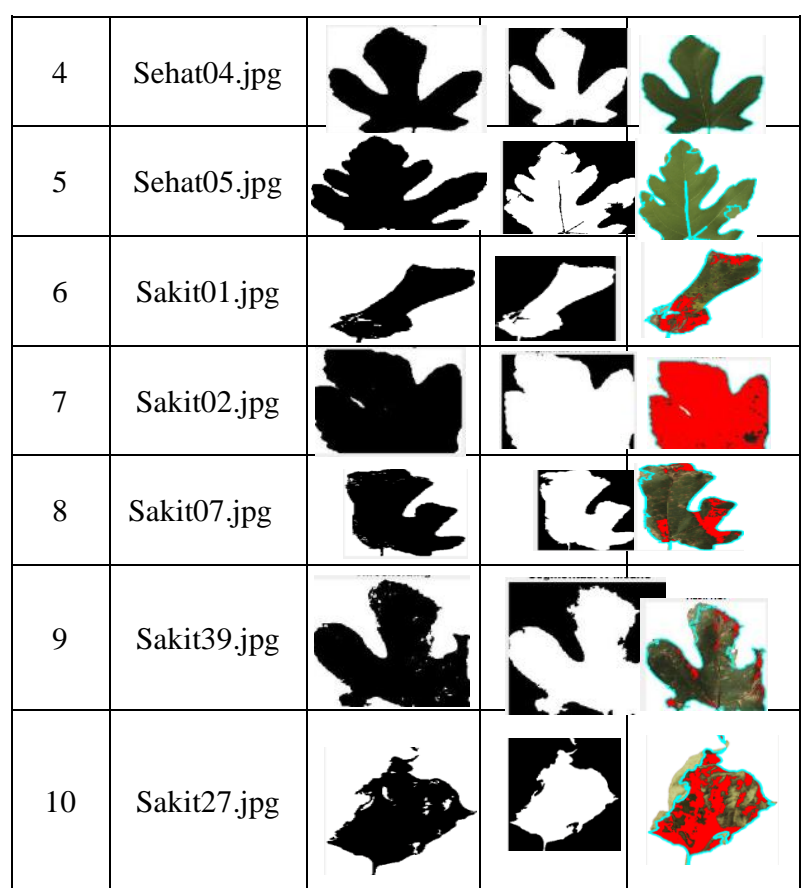

5) Ekstraksi Fitur Gray Level Co-Occurrence Matrix

Nilai dari ekstrasi fitur Gray Level Co-Occurrence Matrix merupakan nilai-nilai yang didapatkan dari metode yang dilatihkan dan diujikan pada 120 citra daun tin sehat dan sakit. Dengan komposisi data citra pelatihan daun tin sehat dan sakit sebesar $60 \%$, sedangkan untuk citra daun tin sehat dan sakit data citra pengujian sebesar 40\%. Pada penelitian ini digunakan analisis ciri Gray Level Co-Occurrence Matrix seperti : contrast, correlation, energy dan homogeneity.

Selanjutnya hasil dari ekstrasi fitur Gray Level CoOccurrence Matrix pada data pelatihan dan penggujian dari citra daun tin sehat dan sakit diklasifikasikan menggunakan Algoritma C4.5 dan Algoritma Naïve Bayes guna mendapatkan hasil akurasi pelatihan dan pengujian untuk kedua algoritma tersebut.

\section{6) Hasil Pelatihan Citra Daun Tin}

Pada tahapan ini merupakan hasil dari pelatihan citra daun tin dengan menggunakan beberapa algoritma pengujian. Berikut hasil pelatihan:

\section{7) Hasil Pelatihan Klasifikasi Algoritma C4.5}

Hasil pelatihan 80 citra daun tin pada ekstrasi ciri Gray Level Co-Occurrence Matrix dengan klasifikasi Algoritma C4.5 ditemukan data benar sejumlah 73 citra dan data salah sejumlah 7 citra dengan akurasi sebesar 90\%. Hasil akurasi pelatihan dengan klasifikasi Algoritma C4.5 citra daun tin dapat dilihat pada Gambar 7. 


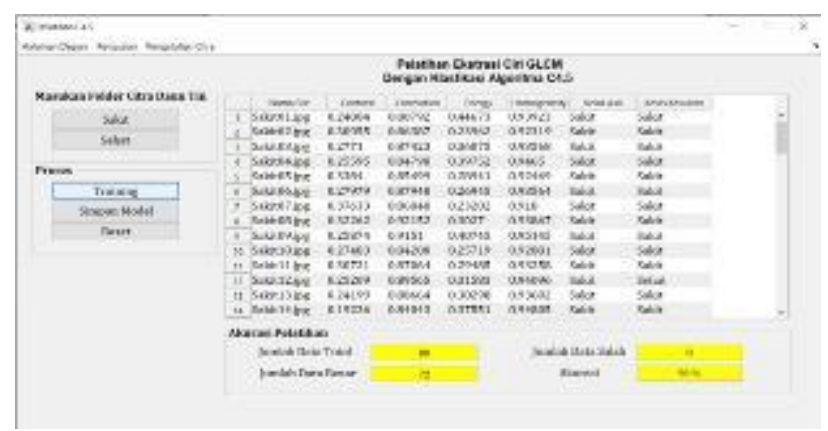

Gambar 7. Hasil Klasifikasi Agoritma C4.5

8) Hasil Klasifikasi Decision Tree

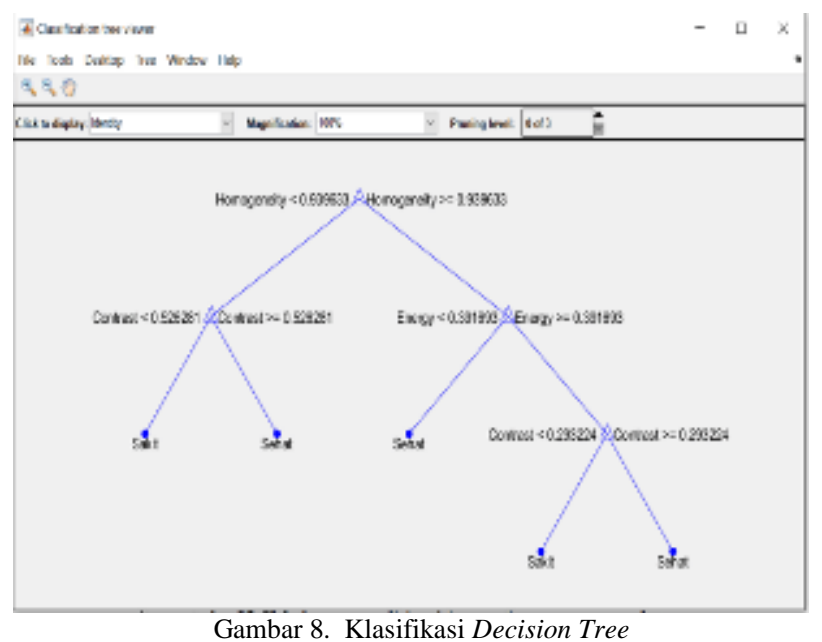

Pada Gambar 8 diatas menggambarkan alur dari pemprosesan classification tree. Jika nilai homogeneity kurang dari 0.939633 dan nilai contrast kurang dari 0.526281 maka citra daun tin akan dikatakan sakit. Jika nilai homogeneity kurang dari 0.939633 dan nilai contrast lebih besar atau sama dengan 0.526281 maka citra daun tin akan dikatakan sehat. Jika homogeneity lebih besar sama dengan 0.939633 dan nilai energy kurang dari 0.391693 maka citra daun tin akan dikatakan sehat. Jika homogeneity lebih besar sama dengan 0.939633 dan nilai energy lebih lebih besar sama dengan 0.391693 maka citra daun tin akan dikatakan sehat. Jika homogeneity lebih besar sama dengan 0.939633 dan nilai contrast kurang dari 0.293224 maka citra daun tin akan dikatakan sakit. Dan jika homogeneity lebih besar sama dengan 0.939633 dan nilai contrast lebih besar sama dengan 0.293224 maka citra daun tin dikatakan sehat.

9) Hasil Pelatihan Klasifikasi Algoritma Nä̈ve Bayes Hasil pelatihan 80 citra daun tin pada ekstrasi ciri Gray Level Co-Occurrence Matrix dengan klasifikasi Algoritma Nä̈ve Bayes ditemukan data benar sejumlah 67 citra dan data salah sejumlah 13 citra. Akurasi klasifikasi dengan Algoritma Nä̈ve Bayes didapatkan sebesar $83.75 \%$. pada menu hasil confusion matrix didapatkan hasil prediksi hasil daun tin sakit terdeteksi sehat sebanyak 5 citra daun dan pada daun tin sehat terdeksi sakit sebanyak 8 citra daun. Hasil yang didapatkan pada cross validation dengan pengujian jumlah K-fold 10 didapatkan hasil tingkat error sebesar 0,1875. Berikut hasil pelatihan dengan klasifikasi Algoritma Nä̈ve Bayes pada Gambar 4.5 dibawah. Berikut hasil pelatihan dengan klasifikasi Algoritma Nä̈ve Bayes pada Gambar 9.

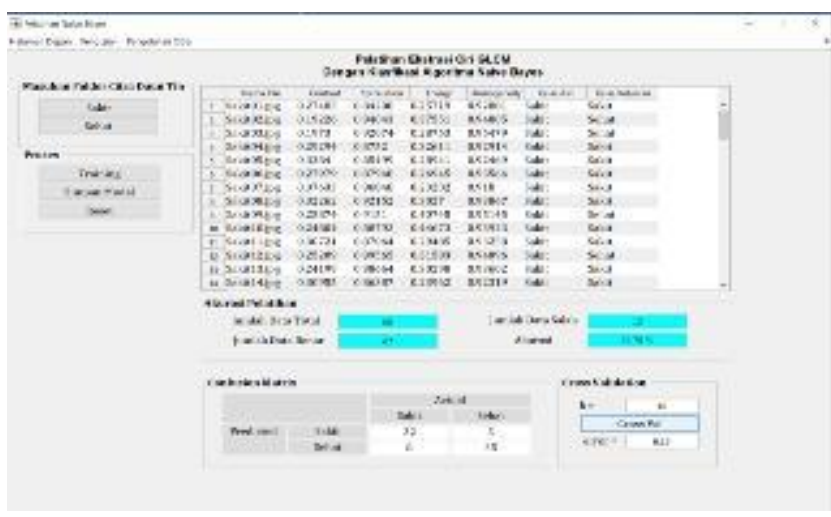

Gambar 9. Hasil Klasifikasi Algoritma Nä̈ve Bayes

10) Hasil Pengujian Citra Daun Tin Sehat Dan Sakit

Pada tahapan ini merupakan hasil dari pengujian citra daun tin dengan menggunakan beberapa algoritma pengujian. Berikut hasil pengujian:

\section{1) Hasil Pengujian Klasifikasi Algoritma C4.5}

Hasil pengujian 40 citra daun tin pada ekstrasi ciri Gray Level Co-Occurrence Matrix dengan klasifikasi Algoritma C4.5 ditemukan data benar sejumlah 35 citra dan data salah sejumlah 5 citra. Akurasi klasifikasi dengan Algoritma C4.5 didapatkan sebesar 87.5\%. Hasil akurasi pengujian dengan klasifikasi Algoritma C4.5 dapat dilihat pada Gambar 10.

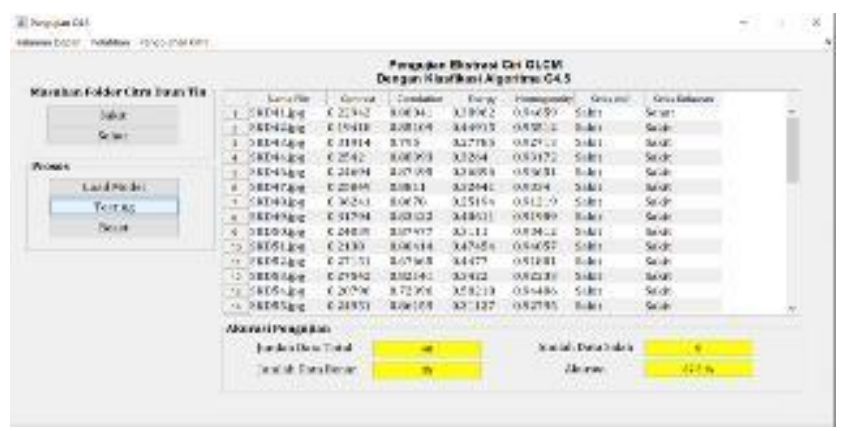

Gambar 10. Hasil Pengujian Klasifikasi Algoritma C4.5

12) Hasil Pengujian Klasifikasi Nä̈ve Bayes

Hasil pengujian 40 citra daun tin pada ekstrasi ciri Gray Level Co-Occurrence Matrix ditemukan data benar sejumlah 36 citra dan data salah sejumlah 4 citra. Untuk hasil akurasi klasifikasi dengan Algoritma C4.5 pada citra daun tin didapatkan sebesar $90 \%$. Hasil akurasi pengujian dengan klasifikasi Algoritma Nä̈ve Bayes citra daun tin dapat dilihat pada Gambar 11. 


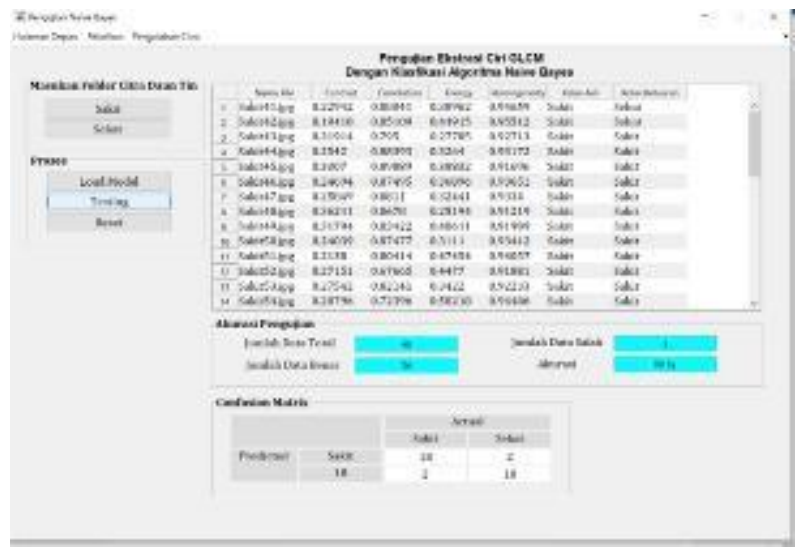

Gambar 11. Hasil Pengujian Klasifikasi Algoritma Nä̈ve Bayes

13) Hasil Komparasi Algoritma C4.5 Dan Algoritma Nä̈ve Bayes

TABEL V

HASIL PELATIHAN ALGORITMA C4.5 DAN ALGORITMA NAÏVE $B A Y E S$

\begin{tabular}{|c|c|c|c|c|c|c|c|}
\hline \multicolumn{9}{|c|}{ Hasil Klasifikasi Pelatiban Citm Daun Tin } \\
\hline \multicolumn{4}{|c|}{ Algoritma C4.5 } & \multicolumn{3}{c|}{ Algoritmai Natve Rayes } \\
\hline Astas & $\begin{array}{c}\text { Kelas } \\
\text { Keluaran }\end{array}$ & $\begin{array}{c}\text { Jumlah } \\
\text { Data } \\
\text { Salah }\end{array}$ & Akurasi & $\begin{array}{c}\text { Kelas } \\
\text { Asli }\end{array}$ & $\begin{array}{c}\text { Kelas } \\
\text { Keluaran }\end{array}$ & $\begin{array}{c}\text { Jumlahh } \\
\text { Data } \\
\text { Salah }\end{array}$ & Akurasi \\
\hline 80 & 73 & 7 & $90 \%$ & 80 & 67 & 13 & $83.75 \%$ \\
\hline
\end{tabular}

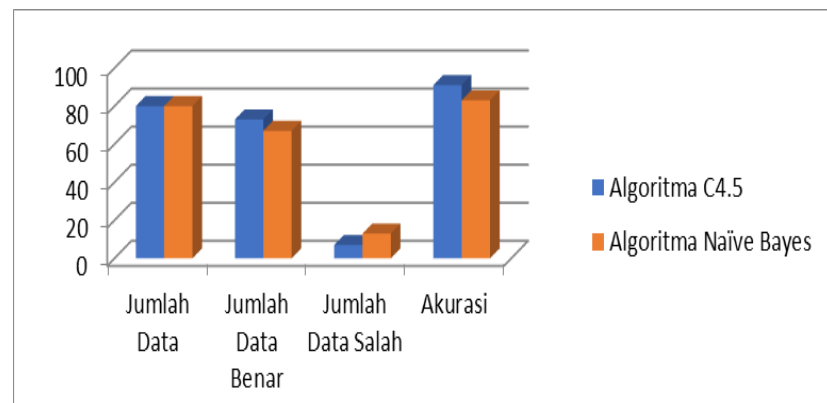

Gambar 12 Grafik Pelatihan Algoritma C4.5 dan Algoritma Nä̈ve Bayes

Hasil pelatihan citra daun tin pada klasifikasi Algoritma C4.5 dan Algoritma Nä̈ve Bayes, didapatkan nilai akurasi tertinggi pada algoritma C4.5 sebesar 91.25\%. Sedangkan pada pelatihan Algoritma Nä̈ve Bayes citra akurasi yang didapatkan $83.75 \%$.

TABEL VI

HASIL PENGUJIAN ALGORITMA C4.5 DAN ALGORITMA NAÏVE $B A Y E S$

\begin{tabular}{|c|c|c|c|c|c|c|c|}
\hline \multicolumn{8}{|c|}{ Hasil Klasifisasi Pengujan Citra Daun Tin } \\
\hline \multicolumn{4}{|c|}{ Algovita C4.5 } & \multicolumn{4}{|c|}{ Algorilma Natre Bayes } \\
\hline $\begin{array}{l}\text { Kelas } \\
\text { Asli }\end{array}$ & $\begin{array}{c}\text { Kelas } \\
\text { Keluaran }\end{array}$ & $\begin{array}{c}\text { Jumlah } \\
\text { Datz } \\
\text { Salah }\end{array}$ & Akurasi & $\begin{array}{l}\text { Kelas } \\
\text { Asli }\end{array}$ & $\begin{array}{c}\text { Kelas } \\
\text { Kelnaran }\end{array}$ & $\begin{array}{c}\text { Jumlah } \\
\text { Datz } \\
\text { Szlah }\end{array}$ & Alsurasi \\
\hline 40 & 35 & 5 & $875 \%$ & 40 & 35 & 4 & $9 \% \%$ \\
\hline
\end{tabular}

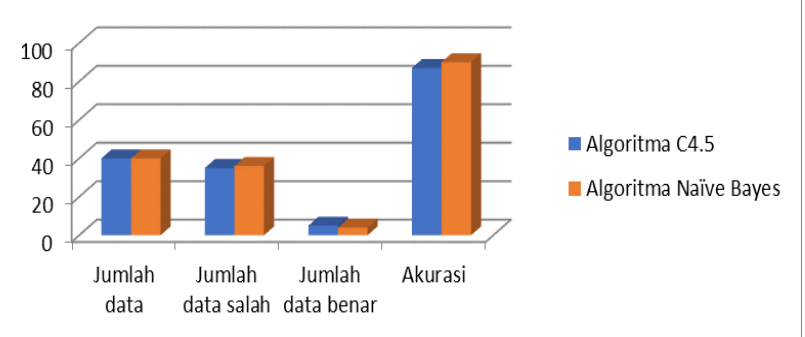

Gambar 14 Grafik Pengujian Algoritma C4.5 dan Algoritma Nä̈ve Bayes

Hasil pengujian citra daun tin pada klasifikasi algoritma C4.5 dan algoritma Nä̈ve Bayes didapatkan nilai akurasi tertinggi pada algoritma Nä̈ve Bayes sebesar $90 \%$, sedangkan pada pengujian algoritma C4.5 citra akurasi yang didapatkan $87.5 \%$.

14) Implementasi Dan Hasil

Berikut merupakan hasil implementasi penelitian yang telah dibuat dalam bentuk GUI Matlab.

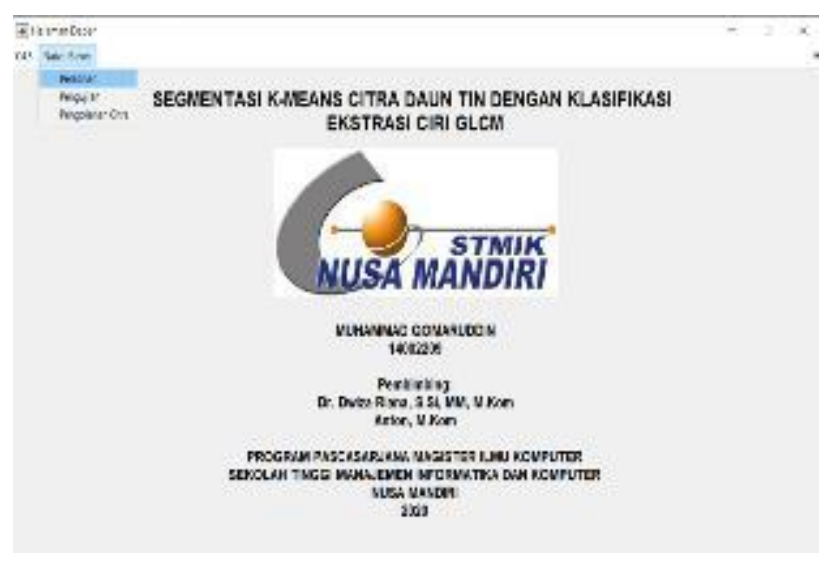

Gambar 15. Menu dari Algoritma C4.5 Dan Algoritma Naïve Bayes

Pada Gambar 15 merupakan tampilan menu dari Algoritma C4.5 dan Algoritma Nä̈ve Bayes. Menu pelatihan dan pengujian digunakan untuk mengekstrasi ciri Gray Level Co-Occurrence Matrix dengan klasifikasi Algoritma C4.5 dan Algoritma Nä̈ve Bayes. Pada menu pengolahan citra digunakan untuk melakukan pengolahan citra daun tin.

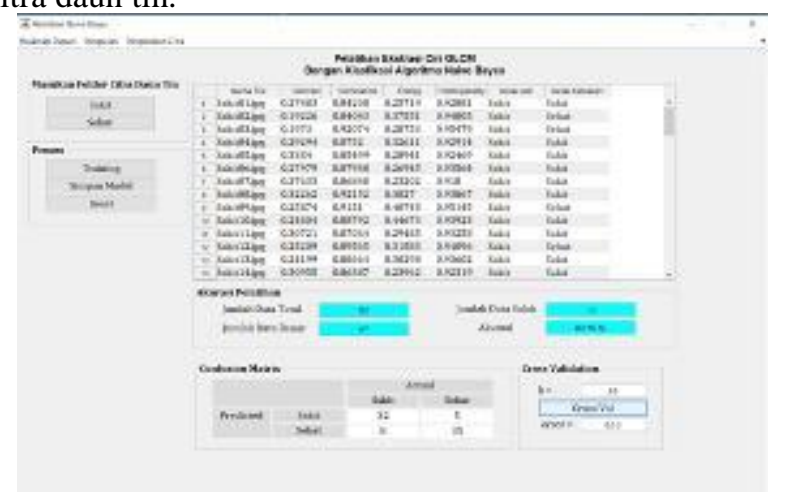

Gambar 16. Menu Pelatihan Algoritma Naïve Bayes 
Pada Gambar 16 merupakan tampilan menu pelatihan algoritma Naïve Bayes yang digunakan untuk melakukan pelatihan citra daun tin.

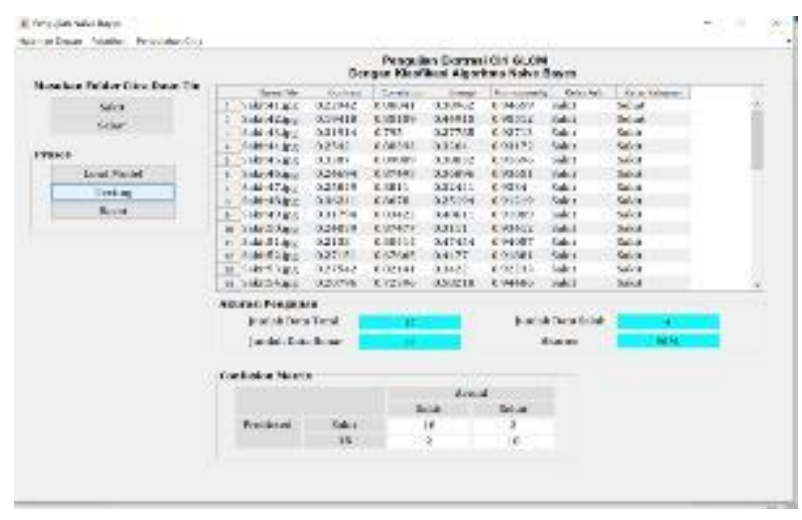

Gambar 17. Pengujian Klasifikasi Algoritma Naïve Bayes

Pada Gambar 17 tampilan menu pengujian terdapat menu masukan folder citra daun tin, lalu pada menu proses terdapat load model digunakan untuk memasukan hasil pelatihan untuk dilakukan pengujian citra daun tin.

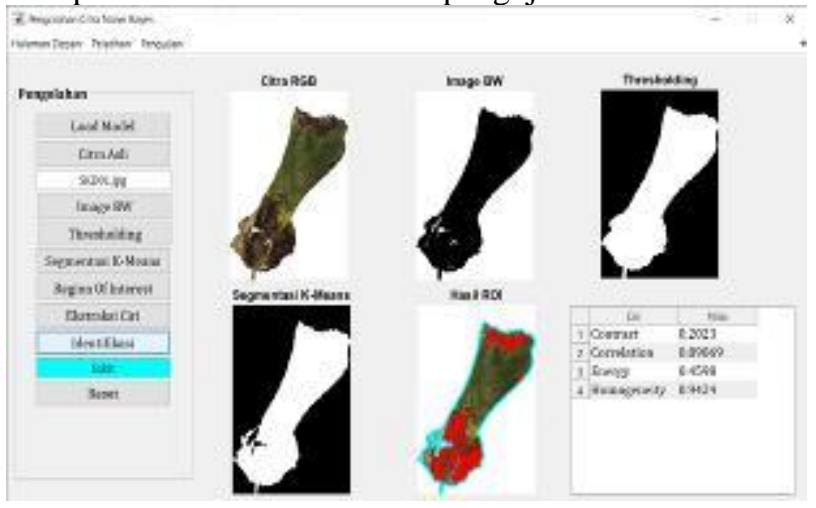

Gambar 18. Hasil Identifikasi Citra Daun Tin Sakit

Salah satu contoh hasil identifikasi citra daun tin yang teridentifikasi sakit dapat dilihat pada gambar 18 diatas dimana hasil dari ekstrasi ciri nilai homogeneity sebesar 0.90559 mengacu pada hasil classification tree viewer (decision) jika kurang dari 0.939633 maka citra dinyatakan sakit.

Dalam bagian ini kesimpulan yang diambil berdasarkan hasil dari penelitian disajikan dengan padat dan singkat, serta pada bagian akhir akan dikemukakan saran yang dapat dijadikan masukkan untuk penelitian selanjutnya

\section{KESIMPULAN}

Bertitik tolak dari pembahasan yang telah dijelaskan pada bab sebelumnya, dapat ditarik kesimpulan beberapa poin sebagai berikut:

1. Dengan Region Of Interest dapat digunakan untuk mengoptimalisasi area pada citra daun tin menggunakan segmentasi K-Means clustering .

2. Perbandingan antara algoritma $\mathrm{C} 4.5$ dan algoritma Nä̈ve Bayes dengan cara mencari akurasi terbaik berhasil didapatkan melalui metode dari nilai GLCM dan didapatkan akurasi terbaik pada pengujian citra daun Tin adalah algoritma Nä̈ve Bayes dengan nilai akurasi sebesar 90\% dibandingkan algoritma $\mathrm{C} 4.5$ hanya $87.5 \%$ saja.

3. Rule dari pohon keputusan decision tree classifier berhasil diimplementasikan pada GUI Matlab guna mencari klaster citra daun tin sehat dan sakit dengan tepat.

\section{DAFTAR PUSTAKA}

[1] R. Purnamasari, D. Winarni, A. A. Permanasari, E. Agustina, S. Hayaza, and W. Darmanto, "Anticancer Activity of Methanol Extract of Ficus carica Leaves and Fruits Against Proliferation, Apoptosis, and Necrosis in Huh7it Cells," Cancer Inform., vol. 18, pp. 0-6, 2019, doi: 10.1177/1176935119842576.

[2] Y. Zhang, Y. Wan, B. Huo, B. Li, Y. Jin, and X. $\mathrm{Hu}$, "Extracts and components of ficus carica leaves suppress survival, cell cycle, and migration of triple-negative breast cancer MDA-MB-231 cells," Onco. Targets. Ther., vol. 11, pp. 43774386, 2018, doi: 10.2147/OTT.S171601.

[3] J. Kamas, M. Nesbitt, and L. Stein, "Te x a s F r u i t a n d N u t Produ c ti o n," pp. 1-7.

[4] S. Hadianti and D. Riana, "Segmentasi Citra Bemisia Tabaci Menggunakan Metode K-Means," Semin. Nas. Inov. dan Tren, p. 2018, 2018.

[5] P. A. Tumbuhan, TUMBUHAN I Disusun oleh Pusat Penerbitan dan Publikasi Universitas Kristen Indonesia Jl . Mayjen Sutoyo No . 2 . Cawang Jakarta Timur, no. July. Pusat Penerbitan dan Publikasi Universitas Kristen Indonesia Jl. Mayjen Sutoyo No. 2. Cawang Jakarta Timur, 2020.

[6] R. R. Waliyansyah, "Identifikasi Jenis Biji Kedelai ( Glycine Max L ) Menggunakan Gray Identification of Glycine Max L Seeds Using Gray Level Coocurance Matrix ( Glcm ) and KMeans Clustering," J. Teknol. Inf. dan Ilmu Komput., vol. 7, no. 1, pp. 17-26, 2020, doi: 10.25126/jtiik202071066.

[7] J. P. Gaikwad, "Region of Interest of Diseased Leaf using Overlapping Window Technique," vol. 10, no. 1, pp. 865-868, 2017.

[8] D. Mondal, D. K. Kole, and K. Roy, "Gradation of yellow mosaic virus disease of okra and bitter gourd based on entropy based binning and Naive Bayes classifier after identification of leaves," Comput. Electron. Agric., vol. 142, no. October, pp. 485-493, 2017, doi: 10.1016/j.compag.2017.11.024.

[9] F. R. F. Padao and E. A. Maravillas, "Using Naïve Bayesian method for plant leaf classification based on shape and texture features," 8th Int. Conf. Humanoid, Nanotechnology, Inf. Technol. Commun. Control. Environ. Manag. HNICEM 2015, no. December, 2016, doi: 
10.1109/HNICEM.2015.7393179.

[10] M. Turkoglu and D. Hanbay, "Recognition of plant leaves: An approach with hybrid features produced by dividing leaf images into two and four parts," Appl. Math. Comput., vol. 352, pp. 114, 2019, doi: 10.1016/j.amc.2019.01.054.

[11] J. Sun, X. Zhou, Y. Hu, X. Wu, X. Zhang, and P. Wang, "Visualizing distribution of moisture content in tea leaves using optimization algorithms and NIR hyperspectral imaging," Comput. Electron. Agric., vol. 160, no. August 2018, pp. 153-159, 2019, doi: 10.1016/j.compag.2019.03.004.

[12] W. D. Septiani, "Komparasi Metode Klasifikasi Data Mining Algoritma C4.5 Dan Naive Bayes Untuk Prediksi Penyakit Hepatitis," None, vol. 13, no. $1, \quad$ pp. 76-84, 2017, doi: 10.33480/pilar.v13i1.149.

[13] S. Hadianti and D. Riana, "Segmentation and Image Analysis for Image Microscopic Pap Smear," vol. xx, no. x, 2017.

[14] V. K. Mishra, S. Kumar, and N. Shukla, "Image Acquisition and Techniques to Perform Image Acquisition," SAMRIDDHI A J. Phys. Sci. Eng. Technol., vol. 9, no. 01, pp. 3-6, 2017, doi: 10.18090/samriddhi.v9i01.8333.

[15] F. R. Lestari, J. Y. Sari, Sutardi, and I. Purwanti, "Deteksi Penyakit Tanaman Jeruk Siam Berdasarkan Citra Daun," no. December, pp. 276283, 2018.

[16] F. G. Febrinanto, C. Dewi, and A. T. Wiratno, "Implementasi Algoritme K-Means Sebagai Metode Segmentasi Citra Dalam Identifikasi Penyakit Daun Jeruk," J. Pengemb. Teknol. Inf. dan Ilmu Komput. Univ. Brawijaya, vol. 2, no. 11, pp. 5375-5383, 2018.

[17] Eko Prasetyo, "Pengolahan Citra Digital dan Aplikasinya Menggunakan Matlab,” F. S. Suyantoro, Ed. Yogyakarta: Andi Yogyakarta, 2011, p. 404.

[18] S. Informasi, U. B. Insani, P. Diplodia, E. Fitur, N. Network, and D. Tree, "Deteksi Penyakit Pada Tanaman Mangga Dengan Citra Digital : Tinjauan Literatur Sistematis ( SLR )," vol. 7, no. 1, pp. 63-72, 2020.

[19] S. Zahrah, R. Saptono, and E. Suryani, "Identifikasi Gejala Penyakit Padi Menggunakan Operasi Morfologi Citra," no. Snik, pp. 100-106, 2016.

[20] R. V. Nahari et al., "Cow Weight Estimation Using Local Adaptive Thresholding Method And Connected Component Labelling," vol. 1, no. Icst, pp. 148-152, 2018, doi: 10.2991/icst-18.2018.32.

[21] E. Prasetyo and A. M. Matlab, "Bab 8 SEGMENTASI E. Prasetyo, Pengolahan Citra digital dan Aplikasinya Menggunakan Matlab, Yogyakarta: Penerbit ANDI, 2011," 2011.

[22] W. F. Mahmudy, M. A. Rahman, J. Matematika, and U. Brawijaya, "Segmentasi Citra Digital Menggunakan Metode Adaptive Split-and-Merge yang Dimodifikasi,” no. 2, pp. 127-137.

[23] Ulla Delfana Rosiani, Cahya Rahmad, Marcelina Alifia Rahmawati, and Frangky Tupamahu, "Segmentasi Berbasis K-Means Pada Deteksi Citra Penyakit Daun Tanaman Jagung," J. Inform. Polinema, vol. 6, no. 3, pp. 37-42, 2020, doi: 10.33795/jip.v6i3.331.

[24] S. S. FI, Ed., "BAB 6 Pengolahan Citra digital dan Aplikasinya Menggunakan Matlab," Yogyakarta: CV.Andi Offset, 2011, p. 155.

[25] A. Mukminin and D. Riana, "Komparasi Algoritma C4 . 5 , Naïve Bayes Dan Neural Network Untuk Klasifikasi Tanah,” J. Inform., vol 4, no. 1, pp. 21-31, 2017.

[26] E. Kamilah, R. Venantius, H. Ginardi, and C. Fatichah, "Klasifikasi penyakit noda pada citra daun tebu berdasarkan ciri tekstur dan warna menggunakan segmentation-based gray level cooccurrence matrix dan LAB color moments," vol. 3, no. 1, pp. 1-10, 2017.

[27] S. C. Madiwalar and M. V. Wyawahare, "Plant disease identification: A comparative study," 2017 Int. Conf. Data Manag. Anal. Innov. ICDMAI 2017, pp. 13-18, 2017, doi: 10.1109/ICDMAI.2017.8073478

[28] E. Prasetyo and A. M. Matlab, "BAB 9Pengolahan Citra Digital dan Aplikasinya Menggunakan Matlab," Pengolahan., vol. 26, FI. Sigit Suyantoro, Ed. Yogyakarta: CV.Andi Offset, 2011, pp. 283-284. 